EFFECTS OF SERUM FROM PATIENTS WITH KAWASAKI DISEASE ON CULTURED ARTERIAL ENDOTHELIAL AND SMOOTH

Kyune. J. Chung, Kathleen V. O'Brien, Peter Libby. Tufts University School of Medicine, Departments of Pediatrics and Medicine, Boston, Massachusetts.

The possible presence of a toxic substance in the serum of patients with Kawasaki disease (KD) causing the pathogenesis of the disease was investigated by examining the effects of acute the disease was investigated by examining the effects of acute phase serum (Kawasaki serum, KS) from 9 patients with KD on viability and growth of cultured calf aortic smooth muscle (SMC)
and endothelial cells (EC). All sera were heat inactivated, and and endothelial cells (EC). All sera were heat inactivated, and filter sterilized. DNA content of these cultures incubated with KS $(5 \%)$ and in age-matched control sera (CS) were similar after $+0.3 \mathrm{ug} / \mathrm{cm}$. $S M C)$. In these cultures, the rates of protein synthesis measured by tyrosine incorporation from $72-96 \mathrm{~h}$ was $7.8+0.5$ vs. $8.2+0.5 \mathrm{nmo} 1 \mathrm{tyr} / 24 \mathrm{~h} / \mathrm{cm}$ in $\mathrm{EC}$, and $3.0 \pm 0.4 \mathrm{vs}$. $2.2 \mp 0.2 \mathrm{nM} \mathrm{tyr} / \mathrm{cm} / 24 \mathrm{~h}$ in SMC (N.S.). In independent experiments, KS (10\%) promoted DNA and protein synthesis by SMC and EC over $24 \mathrm{~h}$ to the same extent as CS $(10 \%)$. No cytopathic effect due to KS was observed by phase contrast microscopy at any time point or concentration (from 2-10\%). Using DNA content, rates of protein synthesis, and morphologic criteria of viability we observed no difference between the effects of KS and CS on SMC and EC. Therefore, a direct toxic effect of KS does not appear to explain the pathogenesis of the arterial lesions that characterize Kawasaki disease.
QUANTITATION OF VENTRICULAR SEPTAL DEFECT SHUNTING:

$1542 D$ ECHO CONTRAST STIDIES IN ANIMALS; USING A STANDARDIZED EXPERIMENTAL ECHO CONTRAST AGENT Lilliam M. Valdes-Cruz, David J. Sahn, Douglas Larson, Sarah Scagnelli University of Calif. San Diego Med Ctr., San Diego, CA We tested a standardizable right heart echo contrast agent to assess contrast flow in relation to hemodynamics in an animal model with a ventricular septal defect (VSD). We produced VSDs $(8-12 \mathrm{~mm})$ in 4 open chest anesthetized dogs and varied pressures and shunting with aortic (AO) and pulmonary artery (PA) bands. $A O$ and PA flows were measured with electromagnetic flow meters and right (RV) and left ventricular (LV) or AO pressures oband right (RV) and left ventricular (LV) or Ao pressures obtained. Echo 4 chamber views were recorded with an automated
gain control $5 \mathrm{MHz}$ scanner. Duplicate neck vein injections of $3.5 \mathrm{cc}$ of a solution of $1 \mathrm{~g}$ of $\mathrm{SH} \mathrm{U} \mathrm{454,} \mathrm{an} \mathrm{experimental} \mathrm{gas} \mathrm{pro-}$ ducing echo contrast agent (Berliscan, Inc), yielded reproducible RV contrast filling and intensities (220-250 video units) as measured by videodensitometry. Positive contrast jets from $\mathrm{RV}$ to $\mathrm{LV}$ quantified as positive area $\left(\mathrm{cm}^{2}\right) \times$ contrast difference ( $\triangle V D$ ) between positive contrast area and control LV reglons were present whenever RV systolic pressure was $>30 \%$ of aortic pressure, and occurred mainly in diastole. LV to RV negative contrast jets, quantified as area $x \Delta V$ between the negative contrast area and the surrounding opacifled RV, correlated roughly with the magnitude $(\mathrm{QP}: \mathrm{QS})$ of 35 different left-to-right shunts (70 contrast injections) $(r=0.82, p<0.01)$. Bidirectiona shunts were also observed. In this model a standardized echo contrast agent provided quantitative information about flow across VSD's.

\section{MYOCARDIAL HYPERTROPHY.}

PARADOXICAL $B$ RECEPTOR MEDIATED VASOCONSTRICTION IN

152 THE STAGE 24 CHICK EMBRYO. Edward B. Clark, ROSS D. Feldman Norman Hu, C. Cynthia Lai, Pediatric Cardiology, Clinical Pharmacology and the CV Center, University of Iowa, Iowa City, IA

Little is known about neurohumoral control of the embryonic cardiovascular system. We studied the effect of increasing intravenous doses of isoproterenol, epinephrine and norepinephrine on heart rate (HR), mean dorsal aortic blood flow (Q) mean vitelline artery pressure (P) and vascular resistance $(R)$ in the stage 24 ( 4 day) chick embryo. Dorsal aortic blood (R) in the stage 24 ( 4 day) chick embryo. Dorsal aortic blood
velocity was measured with a $20 \mathrm{MHz}$ pulsed-Doppler velocity velocity was measured with a $20 \mathrm{MHz}$ pulsed-Doppler velocity
meter. Pressure was measured with a servo null pressure system. $\beta$ receptor properties were determined using radioligand binding and $\beta$ agonist stimulated adenylate cyclase activity on vitelline vascular bed broken-cell preparation. Isoproterenol >

epinephrine > norepinephrine caused a dose related decrease in 0 , an increase in $R$ but no change in HR or $P$. These effects were blocked by propranolol but unaffected by phenoxybenzamine. were Radio [125: I I indocyanopindolol of $10 \pm 3 \mathrm{pM}$ and a receptor density for [125 I] lodocyanopindolol of $10 \pm 3 \mathrm{pM}$ and a receptor density of $139 \pm 8 \mathrm{fmol} / \mathrm{mg}$ protein. Isoproterenol increased adenylate consistent with a $\beta$ receptor which stimulates adenylate cyclase activity and mediates paradoxical vasoconstriction. Since isoproterenol causes vasodilatation in mature embryos, we speculate $B$ receptor function changes with development. EFFECTS OF CHEMI CAL SYMPATHECTOMY. Mark Cohen, Liebman), The Lillie Frank Abercrombie Section of Cardiology, Department of Pediatrics, Baylor College of Medicine and Texas Children's Hospital, Houston, TX.

To study the influence of sympathetic ingrowth on sinus node (SAN) function, 2 groups of puppies underwent electrophysiologic studies. Eleven puppies ( 20 studies, ages $3-17 \mathrm{w}, \mathrm{m} 9.0$ ) underwent chemical sympathectomy by 6 hydroxydopamine $(60 \mathrm{H})$. Twelve puppies (22 studies, ages $3-25 \mathrm{w}, \mathrm{m}$ 10.9) were controls (C). Testing was repeated after atropine (A) and atropine and propranolol $(\mathrm{A}+\mathrm{P})$.

Resting cycle length (CL) was shortened by $A$, in both $C$ $(\mathrm{p}<.001)$ and $60 \mathrm{H} \quad(\mathrm{p}<.001)$. After A, differences of $\mathrm{Cl}$, sinoatrial conduction time (SACT), and corrected sinus node recovery time (CSNRT) between $\mathrm{C}$ and $60 \mathrm{H}$ were N.S. In C, CSNRT correlated with age $(r=.61, p<.02)$; in $60 \mathrm{H}$ it did not.

In $C$, addition of $\mathrm{P}$ to A lengthened $\mathrm{C1} 71+71 \mathrm{~ms} \quad(\mathrm{p}<.001)$ SACT $9 \pm 10 \mathrm{~ms}(\mathrm{p}<.01)$ and CSNRT $33 \pm 51 \mathrm{~ms}(\mathrm{p}<.05)$. In $60 \mathrm{H}$, addition of $\mathrm{P}$ to $\mathrm{A}$ lengthened $\mathrm{Cl} 71 \mp 31 \mathrm{~ms}(\mathrm{p}<.001)$ and CSNR $27+36 \mathrm{~ms}(\mathrm{p}<.01)$. Change in SACT was N.S.

We $36 \mathrm{~ms}$ (p (i) SAN function responds to beta blockade with and without chemical sympathectomy. (2) SAN automaticity following vagal blockade appears to decrease with age. This relationship is abolished by sympathectomy, and may be due to developing cardiac sympathetic innervation.

\section{Anthony F. Cutilletta and Thomas J. Kelly. The} Johns Hopkins University School of Medicine, Departments of Pediatrics and Molecular Biology and Genetics, Baltimore.

Pressure overload left ventricular hypertrophy (PLVH) results from an increase in the amount and a shift in isozymic forms of certain contractile proteins. The synthesis of proteins not present in the normal myocardium has not been reported. Total LV RNA was prepared from rat $15,1,3,5$, and 7 days after sham operation or PLVH. The $S$ ] met labelled product of the in vitro translation of the RNA was analyzed by 1 and 2D SDS polyacrylamide gel electrophoresis (SDS PAGE). Both in vivo labelled and total cytoplasmic proteins were similarly analyzed. A $19,5000 \mathrm{MW}$ peptide was synthesized in vitro in
PLVH at ld but rapidly disappeared. At $3 \mathrm{~d}, \mathrm{a}$.
$\mathrm{P} 2,000$
$\mathrm{MW}$ peptide appeared in PLVH and gradually diminished by $7 \mathrm{~d}$. These peptides were not translated from the SO rat RNA or from RV RNA. These proteins were not present in the in vitro labelled or total proteins from PLVH at any time. These data suggest that species of RNA coding for proteins not normally present in the heart are expressed in PLVH. Although the present in the heart are expressed in by the PAGE band intensively is significant, these proteins do not appear in the protein populations of the intact myocardium. This discrepancy in expression suggests that these proteins are either precursor forms or have a regulatory role and are rapidly degraded.

\section{6}

SLEEP INFLUENCES THE CARDIOVASCULAR RESPONSE TO HEMORRHAGE IN LAMBS. James E. Fewe 11, Becky J. Williams and Donald E. H1l1, University of Arkansas Little Rock, Arkansas.

Newborns spend a large portion of their time asleep. During the first postnatal month lambs spend about $45 \%$ of their time in quiet sleep (QS) and about $10 \%$ of their time in active sleep (AS). The extent to which sleep affects the cardiovascular response to perturbation in young lambs is unknown. We, response to perturbated the effect of sleep on the cardiovascular therefore, investigated the effect of sleep on the cardiovascular response to an acute venous hemorrhage in 7 lambs aged
days. Each lamb was anesthetized and instrumented for days. Each lamb was anesthetized and instrumented for measurements of electrocorticogram, electro-oculogram, nuchal and diaphragm electromyograms, pulmonary blood flow, aortic and right atrial blood pressures. The lambs were not studied before the third postoperative day. Measurements were made durlng a control period and during a l-min experient wakefulness (OW), QS followed a $10 \mathrm{ml} / \mathrm{kg}$ hemorrhage during quiet wakefulness (ow and AS. Hemorrhage produced similar decreases in right atrial pressure and pulmonary blood flow during the three behavioral states. However, mean aortic pressure decreased more $(p<0$
l-way ANOV) following hemorrhage during AS (75.5 \pm 13.9 to $(76.3 \pm 14.9$ to $72.6 \pm 12.0)$. Calculated systemic vascular resistance increased more $(p<0.05)$ during $Q W$ and $Q S$ than during AS. These results provide evidence that reflex control of the peripheral circulation is altered during AS compared to QS and $\mathrm{QW}$ in lambs. for Medical Sciences, Departments of Pediatrics and Physiology, $65.7 \pm 11.5)$ than during $0 S(72.5 \pm 11.3$ to $70.8 \pm 10.4)$ or $\mathrm{QW}$ 